\title{
Edukasi Menanggulangi Pandemi Covid-19 Berbasis Komuniti untuk Mewujudkan Kekuatan Pentahelix
}

\author{
Lisa Adhani ${ }^{*}$, Bungaran Saing ${ }^{2}$, Hernowo Widodo ${ }^{3}$, Siti Setiawati ${ }^{4}$, \\ Ismaniah $^{5}$ \\ ${ }^{1,2,3}$ Teknik Kimia, Fakultas Teknik, Universitas Bhayangkara Jakarta Raya, \\ JI. Perjuangan Raya, Marga Mulya, Bekasi Utara, Jawa Barat, 17143. Telp/fax. (021) \\ 88955871, lisa.adhani@dsn.ubharajaya.ac.id, \\ bungaran.saing@dsn.ubharajaya.ac.id, hernowo.widodo@dsn.ubharajaya.ac.id \\ ${ }^{4}$ Teknik Informatika, Fakultas Teknik, Universitas Bhayangkara Jakarta \\ Raya, JI. Perjuangan Raya, Marga Mulya, Bekasi Utara, Jawa Barat, 17143. Telp/fax. \\ (021) 88955871, siti.setiawati@dsn.ubharajaya.ac.id \\ ${ }^{5}$ Teknik Industri, Fakultas Teknik, Universitas Bhayangkara Jakarta Raya, \\ JI. Perjuangan Raya, Marga Mulya, Bekasi Utara, Jawa Barat, 17143. Telp/fax. (021) \\ 88955871, ismaniah@ubharajaya.ac.id \\ *Korespondensi : lisa.adhani@dsn.ubharajaya.ac.id
}

\begin{abstract}
The theme of this PKM is Education to Overcome the Pandemic Covid-19 CommunityBased to Realize the Power of Pentahelix in the midst of society. Overcoming the community-based Covid-19 pandemic is a major concern at this time, where local people are empowered to form community that will become agents of change in the communities in overcoming Covid-19, breaking the chain of transmission as well as monitoring the implementation of the new normal life era. The Pentahelix is a method of optimizing the 5 (five) strengths (Government, community (society), academics, entrepreneurs and social media) that the government is currently developing as an effort to accelerate the handling of covid-19. Education is carried out by providing assistance to form communities in Kampung Karang Mulya, Desa Karang Satria, Tambun, Bekasi, that implement strategic policies in handling Covid-19 through the formation of young satgas post.
\end{abstract}

Keywords : Young satgas post, pentahelix, community based, agent of change

\begin{abstract}
Abstrak
Tema PKM ini adalah Edukasi Menanggulangi Pandemi Covid-19 Berbasis Komuniti Untuk Mewujudkan Kekuatan Pentahelix. Penanggulangan pandemi Covid-19 berbasis masyarakat menjadi perhatian utama saat ini, dimana masyarakat setempat diberdayakan untuk membentuk komunitas yang akan menjadi agen perubahan di masyarakat dalam mengatasi Covid-19, memutus mata rantai penularan serta memantau penerapan era kehidupan normal baru. Pentahelix merupakan metode optimalisasi 5 (lima) kekuatan (Pemerintah, komunitas (masyarakat), akademisi, pengusaha dan media sosial) yang saat ini sedang dikembangkan pemerintah sebagai upaya percepatan penanganan covid-19. Edukasi dilakukan dengan memberikan pendampingan membentuk komunitas di Kampung Karang Mulya, Desa Karang Satria, Tambun, Bekasi, yang menerapkan kebijakan strategis dalam penanganan Covid-19 melalui pembentukan pos satgas muda.
\end{abstract}

Kata kunci : Pos satgas muda, pentahelix, berbasis komunitas, agen perubahan 


\section{PENDAHULUAN}

Civitas akademika Fakultas Teknik Universitas Bhayangkara Jakarta Raya kembali terpanggil untuk berbuat bagi masyarakat sekitar. Tema Edukasi Menanggulangi Pandemi Covid-19 Berbasis Komuniti Untuk Mewujudkan Kekuatan Pentahelix di Tengah Masyarakat diambil dari tergeraknya usaha pemerintah untuk mengoptimalisasikan kekuatan pentahelix sebagai upaya percepatan penanggulangan pandemi Covid-19 di Indonesia. Kekuatan pentahelix adalah kekuatan 5 (lima) sumber daya yang dimilki suatu negeri, yaitu pemerintah, masyarakat, akademisi, pengusaha, media, yang jika kolaborasi lima kekuatan tersebut berjalan sinergis maka akan dapat menanggulangi wabah yang berskala besar sekalipun, bahkan pandemi (wabah berskala internasional dan diluar kendali) (Wilson, C., \& Jumbert, 2018).

Pandemi Covid-19 diprediksi masih jauh berakhir meskipun tingkat vaksinasi Covid19 terus meningkat di sejumlah negara ("https://www.beritasatu.com/kesehatan/775073/," 2021). Hal ini melahirkan goncangan dahsyat, terutama dari segi ekonomi membuat terjadinya resesi di berbagai negara, laporan berbagai lembaga internasional menunjukkan kontraksi ekonomi yang bisa memicu terjadinya resesi global (Inman, 2020). Karenanya untuk mengatasi resesi global ini, WHO melontarkan gagasan new normal pada akhir April 2020, sebagai bentuk transisi untuk kembali ke kehidupan normal paska pandemic (WHO Media Briefing, 2020). New normal ini lebih merujuk kepada kebutuhan untuk merancang protokol baru berbasis standar kesehatan yang dianggap perlu dalam masa transisi sebelum aktivitas ekonomi dan sosial berfungsi kembali. Protokol ini terkait dengan pola hidup dan perilaku baru yang bisa mencegah COVID-19, yang menjadi prasyarat bagi individu dan diadopsi oleh institusi sosial, politik/pemerintahan, dan ekonomi sebelum menjalankan kembali aktivitasnya.

Di Indonesia, adopsi new normal muncul pada pertengahan Juni 2020, diawali oleh pernyataan Presiden Jokowi untuk mempersiapkan diri hidup berdampingan dengan COVID-19 ("https://nasional.kompas.com/read/2020/05/15/22185601/jokowi-kita-harushidup-berdampingan-dengan-covid-19," 2020). Sebagaimana halnya gagasan WHO, new normal dalam kacamata pemerintah merupakan mekanisme transisi untuk dapat kembali beraktivitas ekonomi dan sosial. Secara operasional, pernyataan Presiden tersebut diikuti dengan sosialisasi berbagai protokol aman dari COVID-19 yang diperlukan di tengah masyarakat, tempat kerja, lembaga pelayanan publik, institusi agama, lalu lintas, pariwisata, dan sebagainya. Secara simbolis Presiden melakukan pengecekan langsung persiapan protokol menuju kembali ke pembukaan ekonomi di sejumlah tempat, seperti mall dan stasiun ("https://www.suara.com/news/2020/05/26/094030/," 2020). Dalam perkembangannya istilah new normal menimbulkan kebingungan di masyarakat, sehingga direspons pemerintah dengan mengubah terminologi menjadi "adaptasi kebiasaan baru" ("https://tirto.id/alasan-pemerintah-ubah-diksi-new-normal-jadikebiasaan-baru-fP9P," 2020).

Adaptasi kebiasaan baru yaitu pembiasaan protokol kesehatan yang telah dicanangkan oleh WHO (Adhani et al., 2020). Protokol kesehatan yang berlaku baik dalam skala internasional, nasional, lokal, maupun wilayah kecil seperti desa/kelurahan hingga kampung/RW harus mengikuti aturan yang ada. Berbagai aturan dan kesepakatan telah banyak ditetapkan, namun ternyata tidak mudah, karena masih terbatas pada kebijakan yang sifatnya umum. Kurangnya sosialisasi hingga lapisan bawah juga menjadi penyebab kebiasaan baru yang dicanangkan masih membingungkan masyarakat, sehingga belum terlaksana dengan baik (Adhani, 2020). Karenanya dipandang perlu dilakukan koordinasi yang lebih terarah dalam implementasi di tengah masyarakat. Mengingat Indonesia merupakan negara yang multi kultural dengan berbagai keragaman, sehingga diperlukan pengelolaan bersama antar berbagai lembaga (Adhani, 2020). Konsep kolaborasi Penta Helix yang diusung oleh Gugus Tugas Covid-19, seperti yang disampaikan oleh Kepala Gugus Tugas Covid-19 Doni Monardo bahwa penting melakukan kerjasama antar lini di masyarakat, mulai tingkat Provinsi hingga RT/RW secara aktif ("https://www.merdeka.com," 2020). 
Konsep Kolaborasi pentahelix akan menjadi 5 (lima) pilar kekuatan dalam menangani bahkan mempercepat penanggulangan Covid-19. Lima pilar kekuatan tersebut adalah pemerintah, masyarakat/komunitas, akademisi, pengusaha, dan media yang jika berkolaborasi dengan baik akan mempercepat tercapainya tujuan dan dalam mengatasi masalah (Boin, A., \& 'T Hart, 2010). Konsep ini juga merupakan pendekatan yang dipilih oleh Badan Nasional Penanggulangan Bencana (BNPB) untuk melakukan rekonstruksi dan rehabilitasi bencana di Indonesia. Pendekatan ini memaksimalkan penggunaan seluruh sumber daya dan kearifan lokal (Tempo.com, 2020).

Untuk mensukseskan strategi pentahelix yang menjadi kekuatan dalam rangka mempercepat penanganan kasus Covid-19, civitas akademika Fakultas Teknik Universitas Bhayangkara Jakarta Raya mengambil peran sebagai akademisi yaitu memberikan edukasi kepada masyarakat sebagai upaya mempercepat penanggulangan pandemic Covid-19 dan mensosialisasikan pentingnya protokol kesehatan dalam pelaksanaan era kebiasaan baru (Henny Syapitri, Fridalina Tarigan, 2021). Keberhasilan suatu program dalam masyarakat sangat memerlukan keterlibatan berbagai komunitas dalam masyarakat itu sendiri, karena komunitas-komunitas tersebut berasal dari masyarakat dan sangat mengenal kultur masyarakatnya sendiri, sehingga memahami berbagai cara yang sesuai dengan kulturnya untuk memasukkan nilai baru (Ryan, 2020)'(Ife, 2006)'(Zdenek, 2021).

Komunitas yang dibentuk berasal dari masyarakat dan untuk masyarakat yang dijadikan lembaga non resmi yang diakui aparat pemerintah setempat dari RT/RW, kelurahan, kecamatan hingga tingkat provinsi, sehingga aktivitas lebih terarah dan terkoordinir. Jika sebagai suatu lembaga, komunitas memungkinkan terjadinya interaksi individu dalam berbagai peran, tidak hanya peran formal dalam lembaga namun lebih sebagai suara dari warga masyarakat (Ife, 2006). Pengelolaan Resiko Bencana Berbasis Komunitas adalah melibatkan secara aktif masyarakat yang berisiko dalam mengkaji, menganalisis, menangani, memantau, dan mengevaluasi risiko bencana untuk mengurangi kerentanan dan meningkatkan kemampuannya (Rothman, Erlich, 1995). Pengelolan Resiko Bencana Berbasis Komunitas juga merupakan kerangka kerja pengelolaan bencana yang inklusif berkelanjutan dengan melibatkan masyarakat atau memfasilitasi masyarakat untuk terlibat aktif dalam pengelolaan bencana baik perencanaan, implementasi, pengawasan, dan evaluasi (Maskrey, 1998).

\section{ANALISIS SITUASI}

Pengabdian kepada masyarakat (PKM) yang dilakukan civitas akademika Fakultas Teknik dan Fakultas IImu Komputer Universitas Bhayangkara ini dilakukan di Kampung Karang Mulya, Desa Karang Satria, Tambun Utara, Bekasi, Jawa Barat. PKM yang bertemakan Edukasi Menanggulangi Pandemi Covid-19 Berbasis Komuniti Untuk Mewujudkan Kekuatan Pentahelix ini diadakan pada tanggal 08 Januari hingga 08 Februari 2021, berdasarkan informasi dari ketua RW Kampung karang Mulya bapak Nur Farianto, saat itu ada satu keluarga yang sedang isolasi mandiri, dan ada 2 (dua) yang di rawat di rumah sakit. Ketua RW juga menjelaskan bahwa Kampung Karang Mulya didominasi oleh pendatang, pekerja pabrik dan minim dalam kemandirian masyarakat dalam penangan pandemi Covid-19 serta kurangnya kesadaran dalam pelaksanaan kebiasaan baru. Maka berdasarkan kondisi ini, civitas Akademika Universitas Bhayangkara melakukan edukasi kepada masyarakat untuk menggugah kesadaran mereka akan kepedulian kepada keadaan lingkungannya, dan dapat berkerja sama untuk dapat melakukan percepatan penanggulangan pandemic Covid-19.

Tema yang diambil untuk mengatasi permasalahan di kampung Karang Mulya dalam penanggulangan Covid-19 ini adalah Edukasi Menanggulangi Pandemi Covid-19 Berbasis Komuniti Untuk Mewujudkan Kekuatan Pentahelix sebagai upaya berperan aktif pada program pemerintah dalam gerakan pemercepatan penanggulangan Covid-19 di Indonesia. Pentahelix adalah 5 (lima) kekuatan dalam suatu daerah/negara yang merupakan kekuatan besar dalam menanggulangi bencana atau pemercepat tujuan negara. Lima kekuatan itu adalah Pemerintah, Pendidikan, Industri, Media dan 
masyarakat. Masyarakat adalah elemen dasar yang ada pada ujung tombak permasalahan di lapangan. Sehingga Civitas Akademika Universitas Bhayangkara merasa perlu dilakukan pengorganisasian masyarakat dalam bentuk komuniti.

\section{METODE PELAKSANAAN}

Metode Pelaksanaan PKM ini memakai konsep Community Development Practice (Zdenek, 2021). Pembentukan komunitas menuju pembangunan yang berkelanjutan. Dimana pembangunan berkelanjutan cenderung membutuhkan pendekatan pada tiap bagian pendukung dari pembangunan itu sendiri, yaitu dari pengembangan masyarakat, pemimpin dan profesional. Sering tren jangka pendek yang tampaknya dapat diterima menjadi bencana jika dilihat dalam jangka panjang. Hal yang sangat penting terciptanya pembangunan berkelanjutan adalah mengupayakan publik (dalam hal ini masyarakat) dan pembuat keputusan (pemerintah) untuk memahami implikasi jangka panjang dari tren saat ini selain dampak jangka pendeknya (dalam hal ini fokus pada penangan pandemi Covid-19).

Pendekatan utama lainnya yang tak kalah penting dalam pembangungan berkelanjutan adalah untuk menekankan interkoneksi antara masalah pembangunan dengan masyarakat (komunitas), pemerintah, lembaga pendidikan, pengusaha dan media. Dimana masyarakat yang menjadi subyek pendampingan pembentukan komunitas adalah masyarakta Kampung Karang Mulya, Desa karang Satria, Kecamatan Tambun, Bekasi, Jawa Barat. Yang fokus utamanya adalah masyarakat muda.

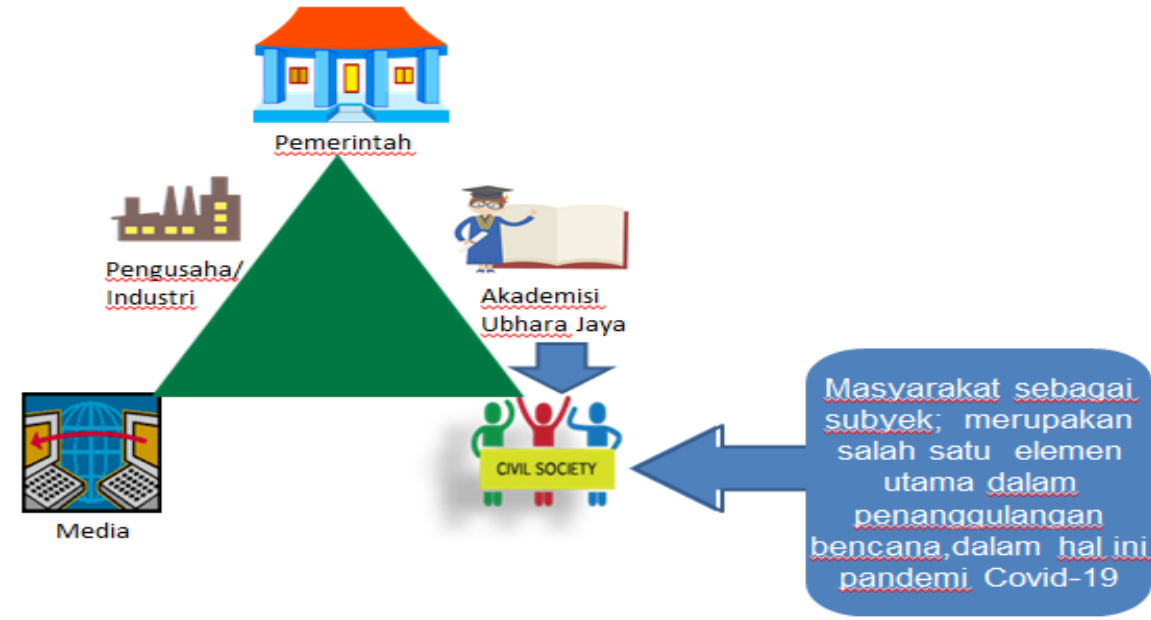

Gambar 1. Alur Metode Pelaksanaan PKM

Konsep Community Development Practice yang dilakukan merupakan pengorganisasian masyarakat (Community Organizing/CO) yaitu proses dan strategi pemberdayaan masyarakat menggunakan konsep $\mathrm{CO}$ yang menitik beratkan pada pengembangan kesadaran kritis dan penggalian potensi local masyarakat. Secara umum metode yang digunakan dalam pengorganisasian masyarakat ini adalah penumbuhan kesadaran kritis, partisipasi aktif, pendidikan berkelanjutan, pembentukan dan penguatan organisasi.

\section{HASIL DAN PEMBAHASAN}

Menurut Dave Beckwith with Cristina Lopes (Dave Beckwith, 1997), Community Organizing adalah :

Proses membangun kekuatan dengan melibatkan rakyat sebanyak mungkin melalui proses:

a. Menemukenali permasalahan, hambatan secara bersama-sama,

b. Menemukenali cara penyelesaian yang diinginkan,

c. Menemukenali pelaku, perangkat lembaga yang ada agar penyelesaian yang dipilih menjadi mungkin dilakukan, 
d. Menyusun sasaran yang harus dicapai dan

e. Membangun lembaga yang efektif dan demokratis.

Sehingga mampu mengembangkan kapasitas untuk menangani dan menampung aspirasi dan kebutuhan yang ada.

Edukasi yang dilakukan sesuai dengan urutan yang dijabarkan Dave Beckwith with Cristina Lopes, pertama dilakukan sosialisasi mengenai pandemi Covid-19, permasalahan, dan hambatannya agar dapat bersama-sama mencari jalan keluar dalam menyelesaikannya, yaitu dalam menanggulangi pandemic Covid-19 terutama di kampung Karang Mulya serta ikut serta untuk program pemerintah sebagai strategi percepatan penanggulangan Covid-19. Hasil sosialisasi bersama mensepakati diadakan pelatihan pembuatan pamflet dan Handsanitizer secara online, sebagai cara penyelesaian mengenalkan masyarakat Kampung Karang Mulya dan menggugah kesadaran masyarakat akan kepedulian terhadap pandemic Covid-19, sehingga bersedia berjuang bersama menjaga lingkungan dan penanggulangan bencana/ pandemi.

Penyebaran cara pembuatan handsanitizer melalui pamflet yang dibuat oleh komunitas muda Karang Mulya yang disebarluaskan dengan ditempel di beberapa titik tempat warga berkumpul juga melalui media WhatsApp yang dimiliki warga. Karena pendidikan yang mayoritas lulusan SLTA memudahkan pelatihan yang diberikan.

Gambar di bawah adalah satgas muda yang terbentuk oleh komunitas muda kampung karang Mulya.

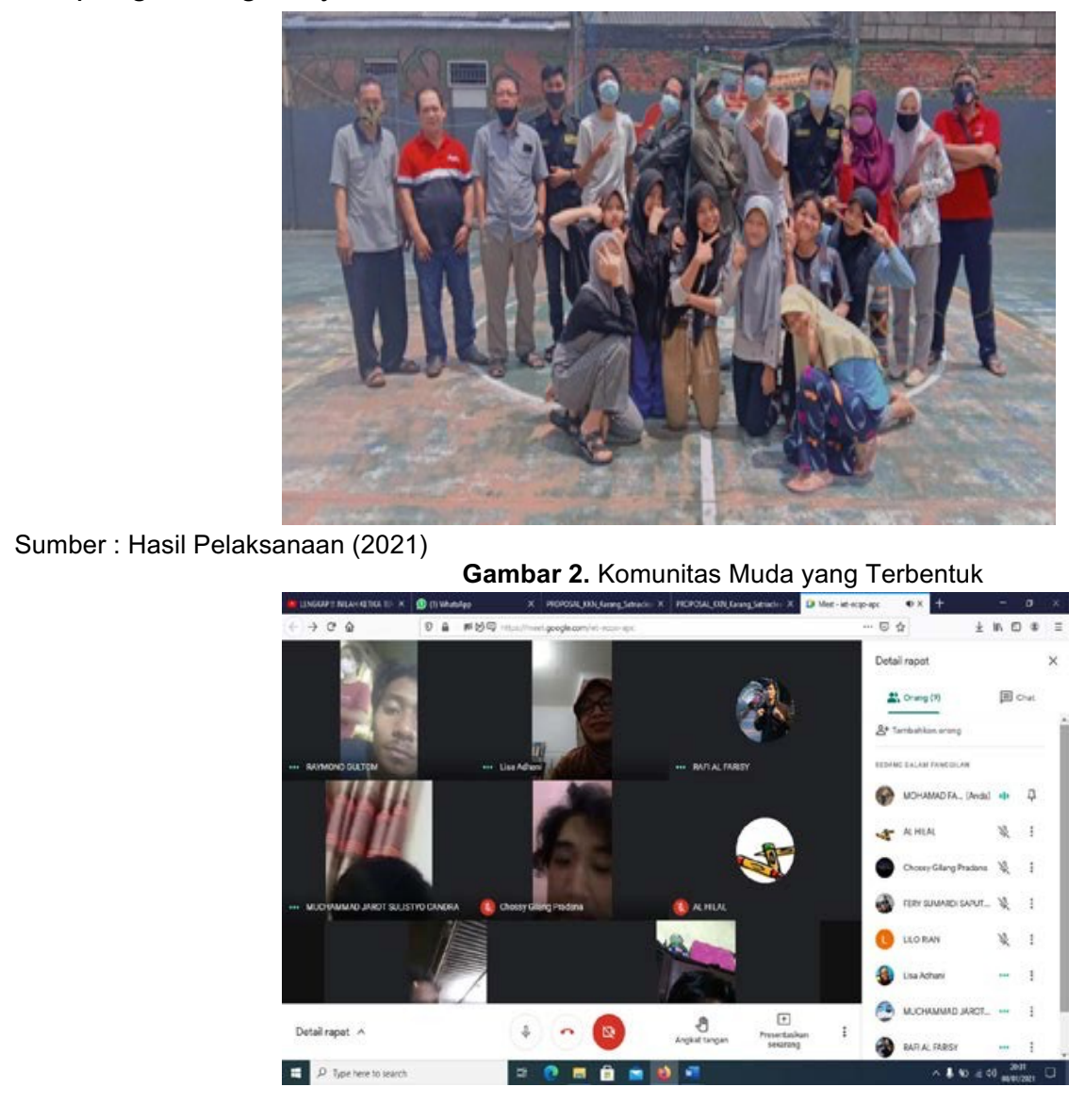

Sumber : Hasil Pelaksanaan (2021)

Gambar 3. Pendampingan secara Online Sepekan Sekali 
Sumber : Hasil Pelaksanaan (2021)
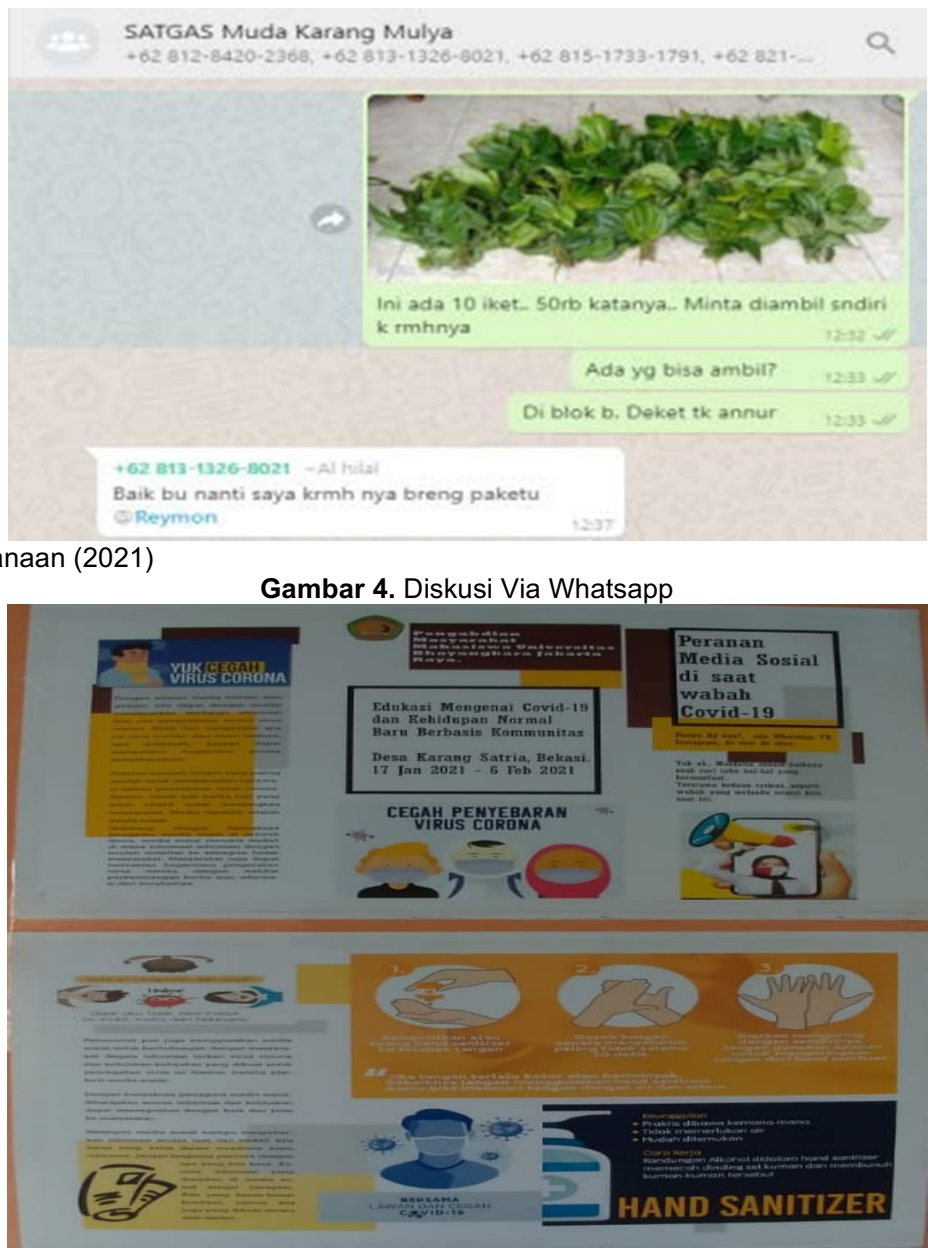

Sumber : Hasil Pelaksanaan (2021)

Gambar 5. Contoh Poster Hasil Edukasi Dibuat oleh Komunitas Muda

Sumber : Hasil Pelaksanaan (2021)

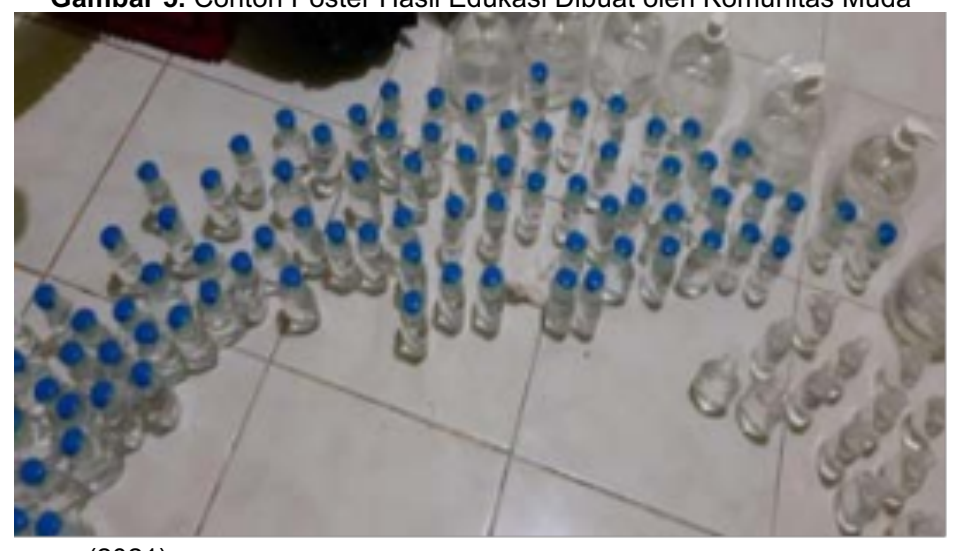

Gambar 6. Hand Sanitizer Daun Sirih Produksi Komunitas Muda 
Sumber : Hasil Pelaksanaan (2021)

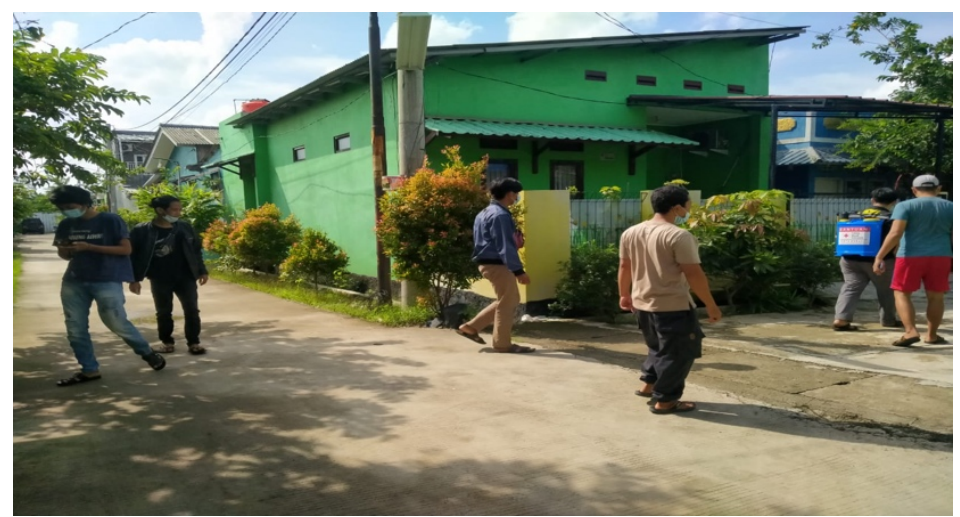

Gambar 7. Penyemprotan Lingkungan Dengan Desinfektan Oleh Komunitas Muda

Civitas akademika Fakultas Teknik Universitas Bhayangkara dalam kegiatan PKM ini mengambil peran sebagai akademisi dalam strategi meningkatkan kekuatan pentahelix dengan menjadi agen penggerak percepatan penanggulangan Covid-19 dalam bentuk edukasi kepada masyarakat, membimbing pembentukan komunitas dari masyarakat dan untuk masyarakat. Kegiatan ini dimulai dengan melakukan diskusi dengan aparat desa karang Satria dan kampung Karang mulya setempat serta karang taruna. Dari hasil diskusi telah di ketahui bahwa pemerintah sudah membuat satuan tugas (satgas) hingga ketingkat kampung / RW dengan satuan tugas tingkat provinsi sebagai komandannya. Sudah juga dilakukan sosialisasi dan upaya pendisiplinan kepada masyarakat yang juga bekerjasama dengan lembaga kesehatan setempat, namun tingkat kedisiplinan masyarakat dinilai masih sulit dilakukan, karena kesadaran dari individu masyarakat itu sendiri yang masih kurang terutama diwilayah yang majemuk dengan dominasi penduduknya adalah pendatang. Maka dipandang perlu mengubah strategi menjadi "down up" untuk mensinergikan kekuatan pentahelix yang menjadi himbauan pemerintah dan diyakini menjadi kekuatan dalam percepatan penanggulangan covid-19. Yaitu dengan membentuk satgas muda yang menjadi komunitas di tengah masyarakat. Komunitas ini diharapkan menjadi agen perubahan sehingga dapat meningkatkan kesadaran masyarakat akan pentingnya kebiasaan baru sebagai pemutus rantai penularan covid-19 dan percepatan penanggulangannya (Christens et al., 2021).

Pembentukan satgas muda merupakan komunitas anak muda dari masyarakat setempat yang peduli akan keadaan wilayahnya dan percepatan penanggulangan Covid19. Civitas akademika, Fakultas Teknik Universitas Bhayangkara memberikan edukasi dan pendampingan kepada anak muda kampung Karang Mulya yang peduli terhadap lingkungannya, untuk membuat komunitas percepatan penanganan covid-19 di wilayahnya. Komunitas ini fokus untuk mensosialisasikan pentingnya era hidup baru untuk melindungi warga yang sehat, dan pencegahan penularan Covid-19. Diskusi yang dilakukan dengan anak muda kampung Karang Mulya mengenai Covid-19, bahayanya, penyebarannya, dan pecegahannya serta implementasi kebijakan pemerintah yang telah digulirkan, menghasilkan kesepakatan pada komunitas muda tersebut untuk membuat suatu wadah informasi di media sosial seperti whatsApp group untuk mempercepat informasi penanggulangan dan pencegahan penularan Covid-19 sebagai upaya percepatan penanganan Covid-19 di lingkungannya. WhatApp group tersebut juga beranggotakan satgas RW dan kelurahan dengan admin (pengelola) dengan sepenuhnya ditangani oleh komunitas muda masyarakat kampung Karang Mulya. Pihak civitas akademika Fakultas Teknik Universitas Bhayangkara Jakarta Raya selain memberikan sosialisasi, edukasi juga mendampingi selama 1 (satu bulan) mulai dari perencanaan, pembentukan dan pelaksanaan komunitas masyarakat muda sebagai satgas muda kampung Karang Mulya yang selanjutnya akan diserahkan pendampingannya kepada satgas RW setempat.

Strategi berbasis komunitas ini bukanlah semata-mata mendorong warga untuk menjadi sukarelawan untuk mengumpulkan bantuan ke warga lainnya, juga bukan 
mendorong satu komunitas lingkup kecil untuk menutup pintu masuk dan mencegah orang dari luar komunitas untuk masuk. Namun strategi berbasis komunitas untuk menangani covid-19 ini lebih berorientasi pada proses untuk menguatkan rasa kebersamaan (sense of community) (Speer \& Hughey, 1995). Namun tujuannya adalah pertama; sebagai wadah dalam proses menggugah kesadaran kolektif (collective awareness) terus menerus bahwa pandemi covid-19 menerjang satu komunitas besar bernama Indonesia, bukan provinsi, kota, kabupaten, atau wilayah tertentu saja kepada masyarakat di lingkungannya. Kedua; wadah proses terus-menerus menggugah solidaritas kolektif (collective solidarity) sehingga diharapkan dapat menjaga keberfungsian komunitas besar bernama Indonesia. Solidaritas kolektif ini akan menghasilkan aksi-aksi solidaritas yang akan dapat merawat kesadaran tentang kebersamaan dan melindungi mereka yang rentan. Hal ini akan mendorong keberfungsian komunitas dan akan meningkatkan keyakinan bersama bahwa mereka mampu mengatasi suatu masalah (Menon \& Allen, 2020). Dengan perkataan lain, komunitas yang kuat merupakan kunci untuk mampu menyelesaikan masalah-masalah komunitas ataupun masalah sosial yang dihadapi oleh komunitas (Zdenek, 2021). Komunitas ini juga dapat dikatakan sebagai lembaga yang terbangun di tengah masyarakat lapisan bawah yang efektif dan demokrasi (poin terakhir Dave Beckwith dalam proses membangun kekuatan masyarakat) (Dave Beckwith, 1997).

Dengan terus tergugahnya kesadaran dan solidaritas kolektif dalam penanganan covid-19, bukan hanya dapat mempercepat penanganan covid-19 tetapi juga menjaga imaji tentang Indonesia, yaitu sebagai satu komunitas yang kompeten, berfungsi, dan bersatu. Sehingga kekuatan pentahelix dapat terwujud secara optimal. Karena corona virus yang terus mewabah di Indonesia, bukan hanya urusan Pemerintah, juga bukan garapan akademisi maupun kepentingan media semata. Walaupun dari aspek regulasi dan kebijakan, itu memang domain pemerintah. Tetapi pada implementasi dan aktualisasi, itu sudah masuk domain masyarakat dengan berbagai karakternya yang menjadi ujung tombak susksesnya kebijakan.

PKM ini dirasakan sebagai langkah strategi civitas akademik Fakultas Teknik Universitas Bhayangkara dalam menjalankan Tri-Dharma Perguruan Tinggi dan berperan disisi akademisi pada kekuatan pentahelix yang dicanangkan pemerintah dalam percepatan penanganan Covid-19. Diharapkan strategi ini mengenai sasaran untuk dapat menjadi pemicu bagi masyarakat Kampung Karang Mulya dalam menjaga kebersihan lingkungan dan meningkatkan kesadaran akan pentingnya pola hidup kebiasaan baru sebagai cara pemutus penularan Covid-19 serta upaya percepatan penanganan Covid19. Dimana anak-anak muda kampung Karang Mulya dapat menjadi agen perubahan dan contoh bagi masyarakat sekitarnya.

\section{KESIMPULAN DAN REKOMENDASI}

Akademika Fakultas Teknik Universitas Bhayangkara mengambil kesimpulan berdasarkan pengabdian masyarakat yang telah dilakukan, hal yang paling penting dan mendasar dalam mensukseskan kebiasaan hidup baru adalah mendorong kesadaran dan kemandirian masyarakat. Dalam percepatan penanganan Covid-19, pemberdayaan masyarakat sangat diperlukan sebagai kekuatan mendasar dari bagian dari kekuatan pentahelix (pemerintah, komunitas, akademisi, pengusaha dan media).

Hasil dari kegiatan PKM kali ini dinilai dapat memberikan dampak positif kepada masyarakat jika dilaksanakan secara berkelanjutan. Melalui komunitas yang dibentuk akan menghasilkan tim relawan yang akan memperkuat Satgas Covid-19 dari tingkat RW, Desa/Kelurahan hingga tingkat provinsi bahkan Negara, dalam menegakkan protokol kesehatan dengan terus menurus melakukan edukasi, sosialisasi dan mitigasi. Mengimplementasikan kebijakan yang telah dirumuskan pemerintah dengan melibatkan komunitas-komunitas basis tingkat paling bawah merupakan cara yang paling efektif agar dapat dapat diterapkan oleh masyarakat luas, terutama dalam program percepatan penanggulangan Covid-19. Basis komunitas dalam penanganan Covid-19 merupakan sisi yang menjadi ujung tombak penguat dari lima sisi kekuatan pentahelix. Agar 
manifestasi kebijakan dapat berjalan dengan baik dan berkelanjutan. Namun harus ada pemetaan yang jelas bentuk koordinasi dan kolaborasi dari lima sisi kekuatan pentahelix tersebut dari pemerintah, baik pusat maupun daerah.

\section{Ucapan Terima Kasih}

Ucapan terima kasih kami haturkan kepada Universitas Bhayangkara, Kepala Desa Karang Satria, Ketua RW Kampung Mulya dan jajaranya, atas dukungan dan kerjasamanya dalam kegiatan pengabdian kepada masyarakat ini. Semoga hasil PKM ini dapat memberikan manfaat yang berkelanjutan bagi bangsa landonesia, masyarakat Kampung Karang Mulya dan Desa karang Satria pada khususnya

\section{DAFTAR PUSTAKA}

Adhani, L. (2020). Edukasi COVID-19 Dalam Upaya Meningkatkan Kesadaran Masyarakat Terhadap Kehidupan Normal Baru. In PEMBELAJARAN BAIK Kuliah Kerja Nyata Covid-19 (p. 312). FPT PRB.

Adhani, L., Mayadi, Setiawati, S., \& Fadhilla Ramdhania, K. (2020). Sosialisasi Media Sosial dan Pembuatan Hand sanitizer, Hand soap Dalam Rangka Ikut serta Menanggulangi COVID-19. Jurnal Sains Teknologi Dalam Pemberdayaan Masyarakat, 1(1), 11-18. https://doi.org/10.31599/jstpm.v1i1.229

Boin, A., \& 'T Hart, P. (2010). Organising for effective emergency management: Lessons from Research. Australian Journal of Public Administration, 69(4). Retrieved from https://doi.org/10.1111/j.1467-8500.2010.00694

Christens, B. D., Gupta, J., \& Speer, P. W. (2021). Community organizing: Studying the development and exercise of grassroots power. Journal of Community Psychology, (August), 1-16. https://doi.org/10.1002/jcop.22700

Dave Beckwith, with cristina L. (1997). Community Organizing: People: People Power from Grassroots. Center for Community Change. Retrieved from Dave Beckwith dan Cristina Lopes Community Organizing

Henny Syapitri, Fridalina Tarigan, O. S. (2021). Sinergi Pentahelix Sebagai Komitmen Memutus Mata Rantai Penularan COVID-19 Melalui Pos Gagah di Wilayah Mebidang. Jurnal Kreativitas Pengabdian Kepada Masyarakat (PKM), 4, 417-424.

https://nasional.kompas.com/read/2020/05/15/22185601/jokowi-kita-harus-hidupberdampingan-dengan-covid-19. (2020).

https://tirto.id/alasan-pemerintah-ubah-diksi-new-normal-jadi-kebiasaan-baru-fP9P.(2020) https://www.beritasatu.com/kesehatan/775073/. (2021).

https://www.merdeka.com. $\quad$ (2020). $\quad$ Retrieved from https://www.merdeka.com/peristiwa/gugus-tugas-covid-19-ajak-masyarakatkolaborasi-secara-penta-helix-lawan-corona.html

https://www.suara.com/news/2020/05/26/094030/. (2020).

Ife, J. W. T. (2006). Community development: Community-based alternatives in an age of globalisation. Pearson Education.

Inman, P. (2020). A hundred years on, will there be another Great Depression?".

Maskrey, A. (1998). Disaster Mitigation: Community Based Approach. Oxfam., London;

Menon, S. V., \& Allen, N. E. (2020). Community Organizing and Transformative Change in the Response to Domestic Violence in India. American Journal of Community Psychology, 66(1-2), 106-118. https://doi.org/10.1002/ajcp.12427

Rothman, Erlich, T. and C. E. (1995). Strategies of Community Intervention. Illinois: Peacock, Inc. 5th Ed.

Ryan, J. (2020). PERANAN JARINGAN AKTOR DALAM KEBIJAKAN. 3(3), 491-509. https://doi.org/10.35817/jpu.v3i4.15380

Speer, P. W., \& Hughey, J. (1995). Community organizing: An ecological route to empowerment and power. American Journal of Community Psychology, 23(5), 729-748. https://doi.org/10.1007/BF02506989

Tempo.com. (2020). N. Retrieved from https://nasional.tempo.co/read/1206278/kepala- 
bnpb-perkenalkan-pendekatan-pentahelix-penanganan-bencana/full\&view=ok

WHO Media Briefing. (2020). General's opening remarks at the media briefing on COVID19.

Wilson, C., \& Jumbert, M. G. (2018). The new informatics of pandemic response: humanitarian technology, efficiency, and the subtle retreat of national agency. Journal of International Humanitarian Action, 3(1), 1-13.

Zdenek, R. O. (Bob). (2021). Research handbook for community development, edited by Rhonda Phillips, Eric Trevan, and Patsy Kraeger . Journal of Urban Affairs. https://doi.org/10.1080/07352166.2020.1820771 